\title{
An Analysis of Students' Attitudes Towards Twitter Use for Academic Purposes: A Case of Saudi Undergreate Female Students
}

\author{
Ilham Hassan Fathelrahman H. Mansour \\ Marketing - School of Management Studies \\ University of Khartoum - Sudan \\ e.mansour@uofk.edu
}

\author{
Azza Hassan Fathelrahman H. Mansour \\ Education Technology - College of Arts \\ Imam Abdulrahman Bin Faisal University - KSA \\ ahfathelrhman@iau.edu.sa
}

Received 8/5/2019

Accepted 20/10/2019

\begin{abstract}
:
Social media has increasingly been used in higher education classrooms as educators lean on technology to mediate and enhance their teaching and learning process. This study aims to explore students' perceptions and attitudes towards the use of social media as an effective academic tool. 149 Undergraduate Saudi female students, enrolled in four courses at Imam Abdulrahman Bin Faisal University, were surveyed about their attitude towards the use of Twitter in classroom interactions, as well as, their perceptions regarding the use of social media in teaching practice. Findings indicate that, in general, students have positive attitudes toward using Twitter for academic purposes. Additionally, students favorably perceive that Twitter facilitates knowledge sharing, collaborations, and interactions in the classroom but to a lesser extent enhancing their sense of learning.

This study sheds light on the potential opportunities of the use of Twitter in the classroom, and what benefits could it bring to the teaching and learning process in higher education that may affect the quality of the students' learning experience.
\end{abstract}

Keywords: Social media; Twitter; Higher Education; Saudi Arabia.

\section{Introduction:}

Microblogging, such as twitter, is one of the most popular forms of social media, and has grown rapidly and shows a potential for impact on the way people communicate and share information ${ }^{(10)}$. Twitter is a social networking site that offers microblogging services which allow users broadcast short posts called tweets limited to 280 characters. Twitter, as an emerging social media, has been narrowly used in college classrooms across disciplines $^{(1)}$. Social networking tools, like Twitter, are beginning to demonstrate their potential as one of the powerful communication and collaboration tools in social, political, and educational arenas ${ }^{(3)}$. With the increased popularity and exponential growth of Twitter, educators have begun to experiment with it to determine its potential for communication and collaboration, both in and out of the classroom ${ }^{(3)}$. Such social networking site is increasingly playing a role in education ${ }^{(6)}$, and has become widely adopted by the current generation of students ${ }^{(5)}$. Thus, the prominence of social networking sites in people's lives, especially students, has prompted the discussion of social media use in education and its role in improving the quality of student-teacher communication $^{(16)}$.

Several researchers had looked at the use of Twitter for educational purposes at the university level. Their research indicated that Twitter is being used in higher education. For instance, Dunlap \& Lowenthal ${ }^{(9)}$ analyzed the use of Twitter in online courses and found that Twitter is a powerful tool for establishing informal, free-flowing, just-in-time communication between and among students and faculty. DeCosta ${ }^{(7)}$ looked at Twitter as a tool for student-teacher communication that had a positive impact on student learning and promotes collaboration knowledge construction and socially enriched pedagogies. Hung \& Yuen ${ }^{(11)}$ reported a generally positive reaction among students to the knowledge and information-sharing benefits of social media for educational purposes. Other studies have investigated live-tweeting during lectures and tutorials e.g. Croxall ${ }^{(4)}$ found that Twitter enables frequent class discussions and enabled conversations to happen in class more easily while Parry ${ }^{(14)}$ found that Twitter can be an effective tool in the classroom and identified 13 ways in which Twitter can be used 
during class and that it served as a reinforcement/connection between the material and the "real world" with a range of benefits, from more productive classroom conversations. Other research streams have examined Twitter as a tool to support informal learning beyond the classroom (e.g. Ebner et $\mathrm{al}^{(10)}$, and Kassens-Noor $\left.{ }^{(13)}\right)$. Ebner et $\mathrm{al}^{(10)}$ found that Twitter provided students with collaborative learning opportunities and teachers with a means for facilitation of lessons/activities. Kassens-Noor ${ }^{(13)}$ explained the advantages of Twitter as an informal learning tool in encouraging the combined knowledge creation of a group better than individuals' diaries and discussion, as it can facilitates sharing of ideas outside the classroom by an online platform that enables readily available access at random times. On the other hand, Rinaldo et al. ${ }^{(15)}$ explored the use of Twitter, in a business classroom and advocated its benefits for student engagement in experiential learning. His findings revealed that the tool aids in reaching educational goals with particular benefits in cases where the students interact with the professor on Twitter. Similarly, Junco et al. ${ }^{(12)}$ found that students and faculty were both highly engaged in the learning process in ways that transcended traditional classroom activities. An examination of the content of the tweets suggests that students engaged with faculty and each other in a vibrant and connected virtual learning community. The authors also found that Twitter is beneficial for education because it is used to help students develop their social skills and helps foster academic achievement.

Moreover, some specific benefits and uses of Twitter when used in a university classroom environment have been highlighted in previous researches. According to Junco et $\mathrm{al}^{(12)}$ one of the major benefits of Twitter is its ability to connect students and increase engagement among them. Whereas, Dogoriti, et $\mathrm{al}^{\left({ }^{8}\right)}$ found that students acknowledged a good number of social and pedagogical benefits related to the integration of Social Networks Sites in their online learning environment, including: facilitation of communication among students and studentinstructor; student participation and collaboration; and motivation. Bista ${ }^{(1)}$ reports that Twitter is used by students: to receive immediate and frequent course information; to ask questions to the mentor; to update course assignments, and to share helpful information from outside the textbook with their fellow classmates and instructor. Similar findings were earlier reported by Veletsianos ${ }^{(19)}$ who found that Twitter was is to share coursework, communicate and to connect with professionals in the study area. It is clear from the literature that, generally, Twitter provides an ideal space on which students and lecturers instantly interact, either inside or outside the classroom, hence enhances social presence amongst students ${ }^{(8)}$.

In the context of Malaysia Chawinga ${ }^{(2)}$ reported that micro-blogging has proven to be an impetus tool for teaching and learning. It effectively complements blended learning by allowing students contextualize the learning outcomes in relation to course objects; it offers students an opportunity to participate in comprehensive learning where they either individually or collectively help each other; it helps students internalize the course content through reflective learning; and it influences students to tweet a wide range of professional items related to their course of study.

In their efforts to enhance students learning, faculty strives to find ways to integrate emerging technologies such as social media networks into classrooms. It is important to explore students' attitudes and perceptions towards using these social networks into teaching process. This study offers important insights into the appropriateness and usability of Twitter as a teaching means.

However, while latest researches have investigated the potential use of social media tools in the classroom to enhance teaching and learning in higher education, little research has examined students' perceptions and attitudes towards social media use as an academic tool to enhance their educational experience in the Arab world, especially in Saudi Arabia. This paper tries to fill this gap.

Saudi Arabia has the highest number of active Twitter users in the region with 2.4 million users, which accounts for 29 percent (dropped from $40 \%$ in 2014) of all active Twitter users in the Arab world ${ }^{(17)}$.

The purpose of the current study is to explore the views of female students at Imam Abdulrahman Bin Faisal University (Al-Dammam University), regarding the use of twitter for academic purposes.

Specifically, this paper aims to answer the following questions:

- RQ1: What are students' perceptions of using Twitter to enhance the quality of classrooms interactions?

- RQ2: What are students' attitudes towards using Twitter for academic purposes?

- RQ3: What factors impact the students' attitudes towards using Twitter for academic purposes?

\section{Method: \\ Participant:}

Participants for this study consisted of 149 undergraduate students from face-to-face multimedia design courses taught by the coauthor of this paper at the College of Art in Imam Abdulrahman Bin Faisal University in Saudi Arabia. Students in these courses voluntarily participated in the online survey. 


\section{Procedures:}

The data collection method used in this study is a quantitative research technique, which has the form of a cross-sectional, structured, close-ended, selfadministered questionnaire for the gathering of data. To address the research questions, data was collected using Google online survey administered to a group of undergraduate female students enrolled in the fourth year. A convenient sample of 149 female students represents the study population.

The questionnaire consisted of three major sections; the first section is related to the respondents' experience with Twitter. Section two related to the questions that assessed the extent to which the Twitter facilitate knowledge sharing, collaboration and interaction, sense of learning, and the student's' perspectives of using Twitter in the teaching process. Students responded to these items with a five-point Likert scale where (1) represents strong disagreement and (5) represents strong agreement adopted from previous literature (e.g. Barczyk \& Duncan (2013) and Rovai's 2002). Demographic questions related to the respondents' age, gender, and education level are presented in section three.

The reliability of all the variables under investigation was projected and had a Cronbach's Alpha coefficient of 0.93 , which indicates that all the scales used in the study were reliable, thus they can be used to measure the variables under study.

SPSS 25 (Statistical Package for Social Science) is used to analyze the data obtained from the questionnaires. Each questionnaire is coded and entered into the SPSS data file. In order to obtain the results and findings of the research, many analysis techniques are used. The first technique used is the descriptive analyses which are run on the demographics of respondents indicating the sample profile and characteristics. Next, regression analyses are conducted in order to determine the relative importance of the independent variables on attitudes towards using Twitter in classroom communications.

\section{Results and Analysis: \\ Sample Characteristics:}

160 undergraduate females were recruited from the female campus enrolled in the four courses analyzed in this study, of which 149 completed the survey questionnaire with a response rate of (93\%). All the respondents were undergraduate female university students in semester 7 of their fourth year and aged between 20 and 26 years-old, and (4\%) of the students used personal computers.

Concerning the devices they use to access their Twitter account, the data in Figure 1 revealed that the majority of the respondents $(89.3 \%)$ access their Twitter account using their smartphones. Whereas only $(5.4 \%)$ used laptops IPad/tablet and only (1.3\%) used personal computers.

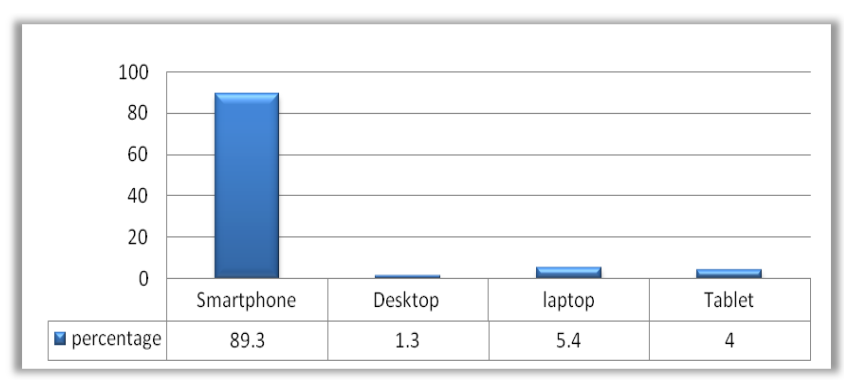

Figure 1: Devices used by students to access Twitter.

With respect to the students frequent checking of their Twitter account, most of the respondents were moderate to intensify users of Twitter. The data in Figure 2, shows that $27 \%$ of the respondents check their account about 4-6 times per day, while $18 \%$ check their Twitter account 7-10 times daily and about $22 \%$ check their account more than 10 times per day.

However, with respect to checking Twitter for the course interactions, it is found that most of the respondents check Twitter less frequently for their course interactions. $83 \%$ of the respondents state that they check their account three times or less per day for course interactions (see Figure 3).

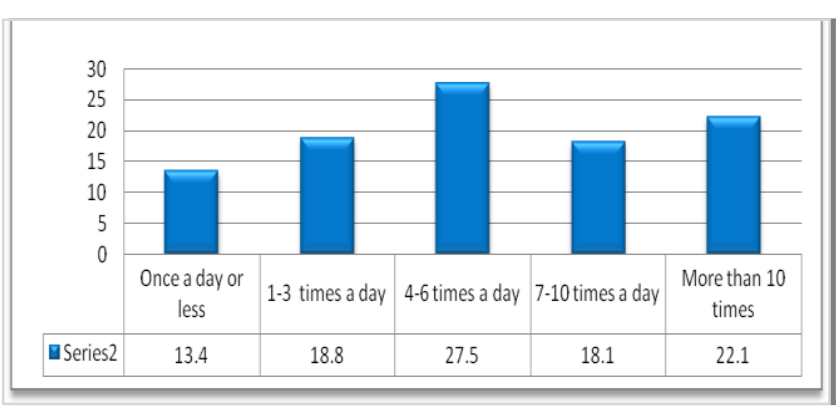

Figure 2: Frequently checking Twitter account.

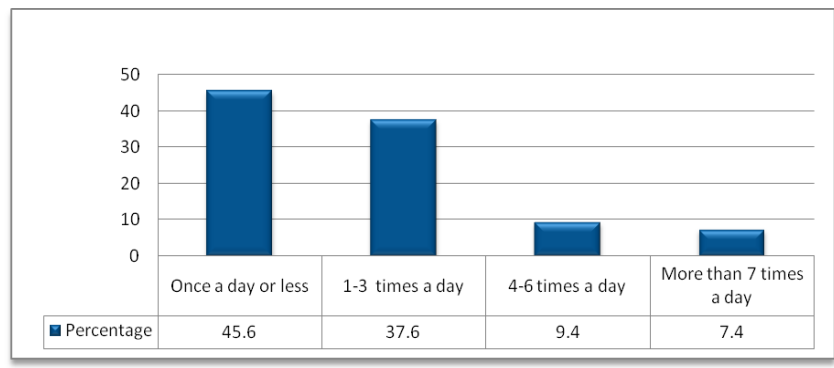

Figure 3: Frequently checking Twitter account for course interactions.

To explore the purpose for which respondents check their Twitter account, the respondents stated a different number of purposes. Data in Figure 4 reveal the most frequent purposes of checking Twitter account stated by the participants are social interactions, not academic interactions. The participants check their account mostly to let others know what is happening in their lives (53\%), to keep in touch with friends (27\%), and to connect with 
people they have lost touch with (20\%), while only $39.6 \%$ of the respondents check Twitter account for academic interaction.

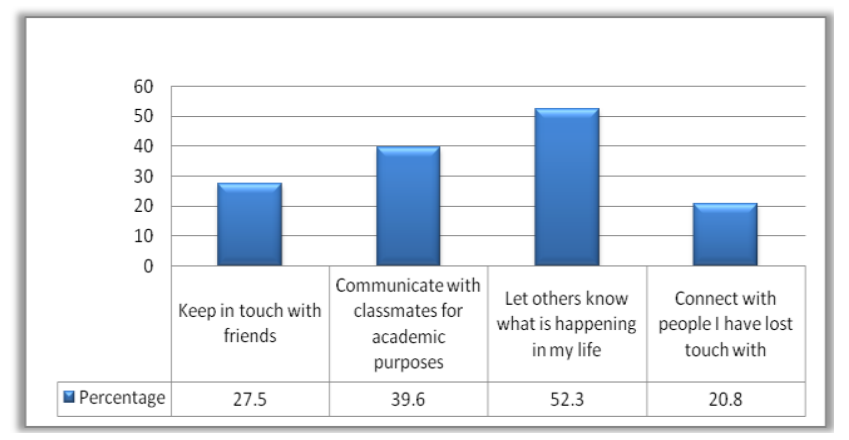

Figure 4: Purpose of checking Twitter accounts.

\section{Students Perceptions Towards Using Twitter for Academic Purposes:}

Findings presented in Table 1 reveal that using Twitter in classroom interaction greatly influence student's overall perceptions of knowledge sharing with a mean value greater than the cutoff point of 3 on the 5-point Likert scale, $(\mathrm{M}=3.77, \mathrm{SD}=1.038)$. The percentage of students agreeing or strongly agreeing with each item on knowledge sharing is moderate. Students agreed and strongly agreed that
Social networking sites allow sharing personal interests are $(48.3 \%)$, that it allows them to find and share educational resources are $(51 \%)$, and that it promotes knowledge sharing, collaboration, and Interaction are $(54.3 \%)$. Furthermore, with regard to the students perception of collaboration and interaction items we found that $(45 \%)$ of the students state that the social networking site allows them to hold forums to discuss topics of interest, (51\%) agreeing and strongly agreeing that Social networking site provides collaborative learning opportunities and (53\%) agreeing that the social networking site allows them to communicate with classmates. With regards to the sense of learning items, $(57.7 \%)$ of the students agreeing or strongly agreeing that with the use Twitter in classroom interaction it is not hard to get help when they have a question while $(57.1 \%)$ agreeing or strongly agreeing that they were given ample opportunities to learn. The overall mean of a sense of community $(\mathrm{M}=3.725, \mathrm{SD}=1.170)$. This data indicate that integrating Twitter in classroom interaction facilitates knowledge sharing, collaboration, and the sense of learning among the students.

Table 1: Students Perceptions towards using Twitter for academic purpose.

\begin{tabular}{|c|c|c|c|c|c|c|c|}
\hline & SDA & DA & $\mathbf{N}$ & $\mathbf{A}$ & SA & Mean & SD \\
\hline \multicolumn{8}{|l|}{ Knowledge Sharing } \\
\hline Social networking site allows me to share my personal interests & 7.4 & 13.4 & 30.9 & 21.5 & 26.8 & 3.47 & 1.23 \\
\hline Social networking site allows me to find and share educational resources & 5.4 & 7.4 & 36.2 & 22.1 & 28.9 & 3.62 & 1.137 \\
\hline Social networking site promotes knowledge sharing collaboration and interaction & 14.1 & 9.4 & 31.5 & 18.1 & 36.2 & 3.64 & 1.290 \\
\hline Overall mean & & & & & & 3.77 & 1.038 \\
\hline \multicolumn{8}{|l|}{ Collaboration and Interaction } \\
\hline Social networking site allows me to hold forums to discuss topics of interest & 14.1 & 9.4 & 31.6 & 11.4 & 33.6 & 3.41 & 1.400 \\
\hline Social networking site provides collaborative learning opportunities & 6.7 & 9.4 & 32.9 & 16.1 & 34.9 & 3.63 & 1.238 \\
\hline Social networking site allows me to communicate with classmates & 8.7 & 10.7 & 27.6 & 16.1 & 36.9 & 3.62 & 1.313 \\
\hline Overall mean & & & & & & 3.55 & 1.151 \\
\hline \multicolumn{8}{|l|}{ Sense of Learning } \\
\hline It is not hard to get help when I have a question & 6.7 & 8.7 & 26.8 & 20.1 & 37.6 & 3.73 & 1.239 \\
\hline I am given ample opportunities to learn & 7.4 & 8.1 & 27.5 & 19.5 & 37.6 & 3.72 & 1.252 \\
\hline Overall mean & & & & & & 3.73 & 1.170 \\
\hline \multicolumn{8}{|l|}{ Perspective } \\
\hline Twitter is personal/social - not for education & 21.5 & 16.1 & 24.2 & 12.1 & 26.2 & 3.05 & 1.483 \\
\hline My privacy would be invaded & 24.2 & 8.1 & 34.2 & 10.1 & 23.5 & 3.01 & 1.450 \\
\hline Overall mean & & & & & & 3.03 & .983 \\
\hline
\end{tabular}

SD - Strongly Disagree, D - Disagree, N - Neutral, A - Agree, SA - Strongly Agree.

With regard to the perspective of using Twitter in classrooms $38.3 \%$ of the respondents agree with the statement that Twitter is a personal and social network not for educational purposes while $37.6 \%$ disagree with the statement. On the other hand, $33.6 \%$ of the students have a privacy concerns and stated that their privacy might be invaded, while $32.3 \%$ disagree with this statement.

\section{Students' Attitudes Towards Using Twitter In Course Interaction:}

To examine Students' Attitudes towards using Twitter in course interaction, ten questions that measure students' attitude towards using Twitter for the academic purpose were presented and analyzed to determine the extent to which students agreeing or strongly agreeing with each item. 
Table 2: Student Attitudes towards using Twitter in course interaction.

\begin{tabular}{|l|c|c|c|c|c|c|c|}
\hline & S & DA & N & A & SA & M & SD \\
\hline Twitter improved the quality of my course & 9.4 & 12.1 & 20.1 & 16.8 & 41.6 & 3.69 & 1.365 \\
\hline Twitter should be introduced in more courses & 14.1 & 9.4 & 18.1 & 20.1 & 38.3 & 3.59 & 1.433 \\
\hline Twitter improve my overall view of the course & 10.7 & 10.7 & 31.5 & 14.8 & 32.2 & 3.47 & 1.328 \\
\hline Twitter was well integrated into the course & 7.4 & 12.1 & 20.8 & 12.8 & 47.0 & 3.80 & 1.341 \\
\hline Twitter in class is more effective than the board & 14.8 & 8.1 & 18.1 & 16.8 & 42.3 & 3.64 & 1.462 \\
\hline I preferred using Twitter over the board & 10.7 & 10.1 & 20.8 & 14.1 & 44.3 & 3.71 & 1.396 \\
\hline Overall experience using Twitter was very positive & 7.4 & 8.1 & 21.5 & 16.8 & 46.3 & 3.87 & 1.287 \\
\hline I felt more connected to fellow students using Twitter & 30.9 & 18.8 & 28.2 & 8.7 & 13.4 & 3.03 & 1.407 \\
\hline Twitter enabled me to contact my instructor more often & 8.1 & 11.4 & 29.5 & 17.4 & 33.6 & 3.57 & 1.280 \\
\hline Twitter enhanced my experience of participation in this course & 5.4 & 7.4 & 26.8 & 18.1 & 42.3 & 3.85 & 1.21 \\
\hline Overall Attitudes & & & & & & 3.25 & 1.002 \\
\hline
\end{tabular}

SD - Strongly Disagree, D - Disagree, N - Neutral, A - Agree, SA - Strongly Agree.

The data presented in Table 2 reveal that the students agreeing and strongly agreeing that their overall experience is very positive are $(63.1 \%)$ and that Twitter enables them to contact their instructor are $(51 \%)$, and that they are well integrated into the course are (59.8\%), that it improves the quality of the course, that it should be introduced in more courses and that Twitter is more effective than the board are $(59.1 \%)$ and that it enhances the experience of participation in the course are $(60.1 \%)$. However, Students are less positive about the role of Twitter in improving the overall view of the course, with a percentage of $(47 \%)$, and in their feeling to be more connected to fellow students, with the percentage of $(16.43 \%)$. In general, students have positive attitudes towards using Twitter in classroom interaction $(\mathrm{M}=3.25, \mathrm{SD}=1.002)$.

\section{Factors Affecting Attitude Towards Using Twitter for Education Purposes:}

In order to examine the factors that might influence the students' attitude towards using Twitter for education purposes, multiple linear regression analysis is carried out. Based on the path coefficients presented in Table 8, two out of the four paths exhibited a P-value are less than 0.05 , while the remaining two are not significant at the 0.05 level of significance. Knowledge Sharing, $(\beta=.342, p, .001)$, together with collaborations $\&$ interactions, $(\beta=.293$, $\mathrm{p}, .019)$ have a significant positive influence on the attitude towards using Twitter for education purposes, whereas sense of learning $(\beta=.139$, $\mathrm{p}$, $.184)$ and perspectives $(\beta=-.091, p, .128)$ show no significant influence on the attitude towards using Twitter for academic purposes. Students perspectives on using Twitter for academic purposes have smallest (non-significant) negative influence on the attitude towards using Twitter for academic purposes $(\beta=$ $.091, \mathrm{p}, 0.184$ ). The value of beta coefficients for knowledge sharing shows the strongest positive relation and therefore can be considered as the most significant antecedent for attitude towards using Twitter for education purposes followed by collaborations \& interactions. Therefore, these two factors should be considered as the antecedents of
Saudi females' attitude towards using Twitter for educational purposes. The explanatory power of the research model is also shown in Table 3. The Rsquare values show that knowledge sharing together with collaborations \& interactions account for $53 \%$ of the variance of attitude towards using Twitter for academic purposes.

Table 3: Regression Analysis.

\begin{tabular}{|c|c|c|c|c|}
\hline Constructs & Beta & t & Sig. & \\
\hline (Constant) & & 4.698 & .000 & $\mathrm{R}=.72$ \\
\cline { 1 - 4 } Knowledge Sharing $\rightarrow$ Attitude & .342 & 3.543 & .001 & $\mathrm{R} 2=.53$ \\
\cline { 1 - 4 } $\begin{array}{c}\text { Collaborations \& } \\
\text { Interactions } \rightarrow \text { Attitude }\end{array}$ & .293 & 2.378 & .019 & $\mathrm{~F}=39.573$ \\
\cline { 1 - 4 } Sense of Learning $\rightarrow$ Attitude & .139 & 1.334 & .184 & $\mathrm{P}=.000$ \\
\cline { 1 - 3 } Perspectives $\rightarrow$ Attitude & -.091 & -1.531 & .128 & \\
\hline
\end{tabular}

Dependent Variable: Attitude towards using Twitter in classroom interactions. Predictors: knowledge sharing, collaborations \& interactions, sense of learning, perspectives

\section{Discussion \& Conclusion:}

The main purpose of this study is to explore students' attitude towards using Twitter for academic purposes. More specifically, it is to investigate factors that might affect their attitude towards using Twitter for academic purposes.

In line with Hung and Yuen ${ }^{(11)}$ and Tur et $\mathrm{al}^{(18)}$, the study finds that, in general, students have positive attitudes toward using Twitter for academic purposes with a considerable amount of diversity among students in terms of their existing experience of Twitter in the teaching process.

As in previous studies, Davis ${ }^{(6)}$ and Dogoriti ${ }^{(8)}$, Twitter has a positive effect on student learning process, over $70 \%$ of the students agree that their experience using Twitter is very positive, it enhances their experience of participation in the course, and they were well integrated into the course, and they preferred using Twitter over the board. These findings can encourage faculty educators to use Twitter as a teaching practice within the context of their course to promote more effective learning for undergraduate students.

On the other hand the findings also reveal that students attitudes are found to be somewhat neutral about whether Twitter improves the quality of the course, or whether it is more effective than the board, that it should be introduced in more courses, or that it 
enables them to contact the instructor more and that it improves their overall view of the course.

However, contradicting the results reported by Evans $^{(5)}$, the students strongly disagree that they felt more connected to fellow students using Twitter. The study also investigates students' perceptions of integrating Twitter into the teaching process, the data suggested that in general Twitter facilitates knowledge sharing, collaboration and interaction, and sense of learning, this is in consistent with Hung $\&$ Yuen $^{(11)}$ who reported a generally positive reaction among students to the knowledge and informationsharing benefits of social media for educational purposes, and with Dogoriti \& Pange ${ }^{(8)}$ who concluded that the integration of social networks sites in online learning environment facilitates student participation and collaboration. In line with De Costa et $\mathrm{al}^{(7)}$ and Ebner et al ${ }^{(10)}$, this study also has identified knowledge sharing, collaboration, and interaction as the variables that have an impact on students' attitude towards using Twitter for academic purposes. Sense of learning and perspective show no impact on students' attitude towards using twitter for educational purposes.

While the study presents several insights into using social networks sites in higher education, some limitations existed. First, the sample used in this study consists of female university students at a single academic institution pursuing undergraduate studies. Therefore, caution should be exercised when generalizing the results. Future research should consider other university populations e.g. males and graduate students or faculty members.

Second, the scope of this study is limited to twitter as a social media tool because of its popularity and intense use in Saudi Arabia. Future studies can build on this study using other social media outlets such as Facebook and SNAP platform in order to facilitate our understanding of using social media in the classroom. Eventually, social media technologies should only be brought into classroom when carefully examined and deemed to improve the learning process.

\section{References:}

1. Bista, K. (2015). Is Twitter an effective pedagogical tool in higher education? Perspectives of education graduate students. Journal of the Scholarship of Teaching and Learning, vol 15, no. 2, pp. 83102.

2. Chawinga, W. D. (2016). Teaching and learning 24/7 using Twitter in a university classroom: Experiences from a developing country. E-Learning and Digital Media, vol. 13, no. (1-2), pp. 45-61.

3. Corbeil, J.R., \& Corbeil, M.E. (2011). The birth of a social networking phenomenon. In
C. Wankel (Ed.) Educating educators with social media: Cutting-edge technologies in higher education, Volume 1, pp. 13-32). Bingley, West Yorkshire, UK: Emerald

4. Croxall B (2010) Reflections on teaching with social media. Chronicle of Higher Education, Available at http://chronicle.com/blogs/profhacker/reflecti ons-on-teaching-with-social-media/24556

5. Evans, C. (2014) "Twitter for teaching: Can social media be used to enhance the process of learning?", British Journal of Educational Technology, Vol 45, No. 5, pp 902-915.

6. Davis, M. R. (2011). 'Safe' social networking tailored for K-12 schools. Education Week, vol.30, no. 35, pp. S17S18.

7. DeCosta, M., Clifton, J., \& Roen, D. (2010). EJ in focus: Collaboration and social interaction in English classrooms. The English Journal, vol. 99, no., 5, pp. 14-21.

8. Dogoriti, E., Pange, J., \& S. Anderson, G. (2014). The use of social networking and learning management systems in English language teaching in higher education. Campus-Wide Information Systems, vol. 3, no.14, pp. 254-263.

9. Dunlap, J. C., \& Lowenthal, P. R. (2009). Tweeting the night away: Using Twitter to enhance social presence. Journal of Information Systems Education, vol. 20, no. 2, pp. 129.

10. Ebner, M., Lienhardt, C., Rohs, M., \& Meyer, I. (2010). Microblogs in higher education: A chance to facilitate informal and process-oriented learning?. Computers \& Education, vol. 55, pp. 92-100.

11. Hung, H. T., \& Yuen, S. C. Y. (2010). Educational use of social networking technology in higher education. Teaching in higher education, vol. 15 , no. 6, pp. 703714.Croxall.

12. Junco, R., Heibergert, G., \& Loken, E. (2010). The effect of Twitter on college student engagement and grades. Journal of Computer Assisted Learning, vol. 27, no. 2, pp. 119-132.

13. Kassens-Noor, E. (2012). Twitter as a teaching practice to enhance active and informal learning in higher education: The case of sustainable tweets. Active Learning in Higher Education, vol. 13, no. 1, pp. 9-21

14. Parry B (2008) Twitter for academia. Available at: http://academhack.outsidethetext.com/home/ 2008/Twitter-for-academia

15. Rinaldo, S. B., Tapp, S., \& Laverie, D. A. (2011). Learning by tweeting: Using Twitter 
as a pedagogical tool. Journal of Marketing Education, vol. 33, no.2, pp. 193-203.

16. Selwyn, N. (2009). Faceworking: exploring students' education-related use of Facebook. Learning, Media, and Technology, vol. 34, no. 2, pp. 157-174.

17. The Arab Social Media Report 2017: Social Media and the Internet of Things: Towards Data-Driven Policymaking in the Arab World, vol. 7. MBR School of Government, Dubai.
18. Tur, G., Marín, V. I., \& Carpenter, J. (2017). Using Twitter in higher education in Spain and the USA. Comunicar: Media Education Research Journal, vol.25, no.51, pp. 19-27.

19. Veletsianos G (2012) Higher education scholars' participation and practices on Twitter. Journal of Computer Assisted Learning. Vol. 28, no. 4, pp. 336-349. 


\section{تحليل اتجاهات الطلاب نحو استخدام تويتر للأغراض الأكاديمية: حالة الطالبات الجامعيات في السعودية}

\author{
عازة حسن فتح الرحمن حاج منصور \\ تكنولوجيا النعليم - الآداب \\ جامعة الإمام عبد الرحمن بن فيصل -السعودية \\ ahfathelrhman@iau.edu.sa
}

$$
\begin{gathered}
\text { الهام حسن فتح الرحمن حاج منصور - مدرسة العلوم الإدارية } \\
\text { التسعة الخرطوم - السودان } \\
\text { e.mansour@uofk.edu }
\end{gathered}
$$

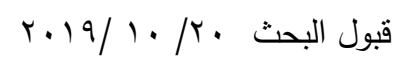

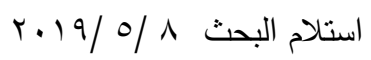

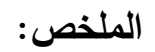

تُشتخم وسائل التواصل الاجتماعي بشكل متزايد في للأغراض الأكاديمية في التعليم العالي حيث بعتمد الأساتذة على التكنولوجيا من أجل

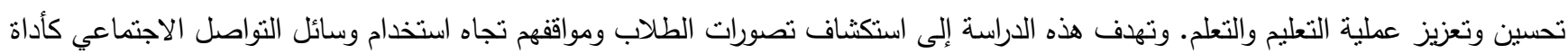

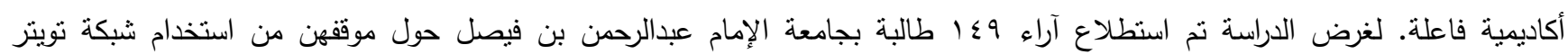
الاجتماعية في التواصل الأكاديمي، وكذللك تصوراتهن فيما يتعلق باستخدام وسائل التواصل الاجتماعي كأداة مساعدة في التدريس.

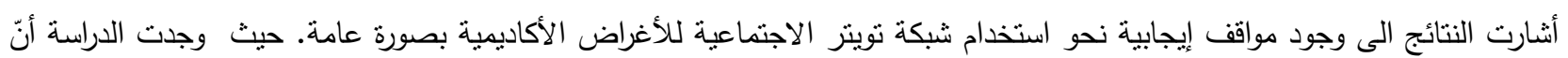

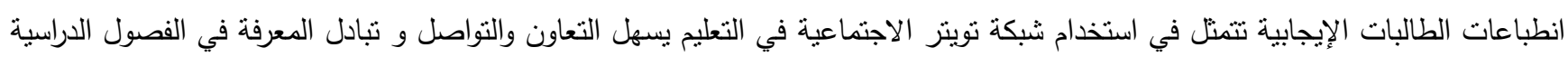
بشكل كبير ولكن إلى حد أقل تعزيز شعورهن بالتعلم. تسلط هذه الدراسة الضوء على الفرص الواعدة من استخدام شبكة تويتر الاجتماعية في الفصول الدراسية والفوائد المرجوة التي يمكن أن يحققها استخدامها في عمليه التعليم والتعلم في التعليم العالي وتأثيرها على جودة تجربه الطلاب التبات التعليمية. الكلمات المفتاحية: شبكات الثواصل الاجتماعي، تويتر ، التعليم العالي، الطالبات الجامعيات، السعودية. 